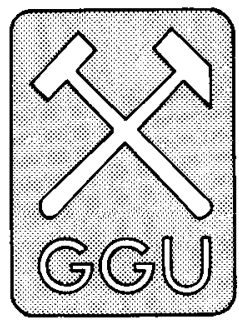

\title{
Publications of the Geological Survey of Greenland 1990
}

\section{Maps in series}

Sheet 14 Skjoldungen. Geological map of Greenland, 1:500 000. 1990 compiled by J. C. Escher.

Quaternary map of the Hall Land - Nansen Land region, North Greenland, 1:1000 000. 1990 compiled by O. Bennike \& M. Kelly.

\section{Map sheet descriptions}

Sheet 1 Sydgrønland. Geological map of Greenland. 1:500 000. Descriptive text. 1990 by F. Kalsbeek, L. M. Larsen \& J. Bondam. 36 pp.

Sheet 12 Scoresby Sund. Quaternary map of Greenland 1:500 000. Descriptive text. Quaternary geology and stratigraphy in the Scoresby Sund region, East Greenland. 1990 by S. Funder. 24 pp.

Neria 61 V.1 Nord, Midternæs 61 V.2 Nord. Geological map of Greenland. 1:100 000. Descriptive text. 1990 by A. K. Higgins. 23 pp.

\section{Bulletins (Bull. Grønlands geol. Unders.)}

159 Conodonts from the Upper Ordovician - Lower Silurian carbonate platform of North Greenland. 1990 by H. A. Armstrong. $151 \mathrm{pp}$.

\section{Reports (Rapp. Grønlands geol. Unders.)}

147 Lower Cambrian trace fossils from Greenland. 1990 edited by J. S. Peel. 62 pp.

148 Current research including Report of Activities, 1989. 1990. 141 pp.

\section{Open File Series}

90/2 Prospecting for base and noble metals in the Íngia area, West Greenland: analytical results. 1990 by B. Thomassen. $16 \mathrm{pp}$.

90/3 Seasonal runoff forecast for Kangerluarsunnguaq near Nuuk/Godthåb, West Greenland. 1990 by R. J. Braithwaite. $17 \mathrm{pp}$.

90/4 Tungsten mineralization in the Nuuk region, West Greenland. 1990 by P. W. U. Appel. 51 pp.

90/5 Gold content of regional stream sediment samples from South Greenland. 1990 by A. Steenfelt. $12 \mathrm{pp}$.
90/6 Structural and economic aspects of the Proterozoic marble on Nûgssuaq, West Greenland. 1990 by A. A. Garde \& B. Thomassen. $14 \mathrm{pp}$.

90/7 Reconnaissance for noble and base metals in the IvigtutKobberminebugt area, South Greenland: analytical results. 1990 by P. Erfurt \& M. Lind. 14 pp.

90/8 Gold occurrences in supracrustal rocks of the Nuuk region, West Greenland. 1990 by P. W. U. Appel. 21 pp.

90/9 Copper, zinc and nickel occurrences in the Nuuk region, West Greenland. 1990 by P. W. U. Appel. 28 pp.

90/10 Reconnaissance and exploration for gold and base metals in the area between Arsuk and Neria Fjords, South-West Greenland. Work performed 1971 to 1985: results and discussion. 1990 by P. Erfurt. 29 pp., app. 59 pp.

\section{Thematic Map Series}

90/1 Regional compilations of geoscience data from the NuukManiitsoq area, southern West Greenland. 1990 edited by A. Steenfelt, L. Thorning \& T. Tukiainen. 9 pp. text +57 maps with legends.

\section{Scientific articles}

Appel, P. W. U. 1990: Mineral occurrences in the 3.6 Ga old Isua supracrustal belt, West Greenland. In Naqvi, S. M. (ed.) Precambrian continental crust and its economic resources. Developments in Precambrian Geology 8, 593-603.

Asmund, G., Christophersen, J.-B. \& Steensboe, J. 1990: Rehabilitation and demolition after the closure of the zinc and lead mine 'Black Angel' at Maarmorilik, Greenland. Proc. 3rd int. Conf. Develop. Commerc. Util. Tech. Polar Reg., Copenhagen, 1990, 744-759.

Bendix-Almgreen, S. E., Clack, J. A. \& Olsen, H. 1990: Upper Devonian tetrapod palaeoecology in the light of new discoveries in East Greenland. Terra Nova 2, 131-137.

Bondam, J. 1990: Greenland. Mining a. Rev. 1990, 193 only. Bondam, J. 1990: Greenland. Int. Mining Yb. 1990, 108-109. Braithwaite, R. J. 1990: Greenland glaciers and the 'greenhouse effect'. Rapp. Grønlands geol. Unders. 148, 51-53.

Braithwaite, R. J. 1990: Effects of glaciers on annual runoff east of Nuuk/Godthåb, West Greenland. Rapp. Grønlands geol. Unders. 148, 87-91.

Braithwaite, R. J. \& Olesen, O. B. 1990: Response of the energy balance on the margin of the Greenland ice sheet to temperature changes. J. Glaciol. 36, 217-221. 

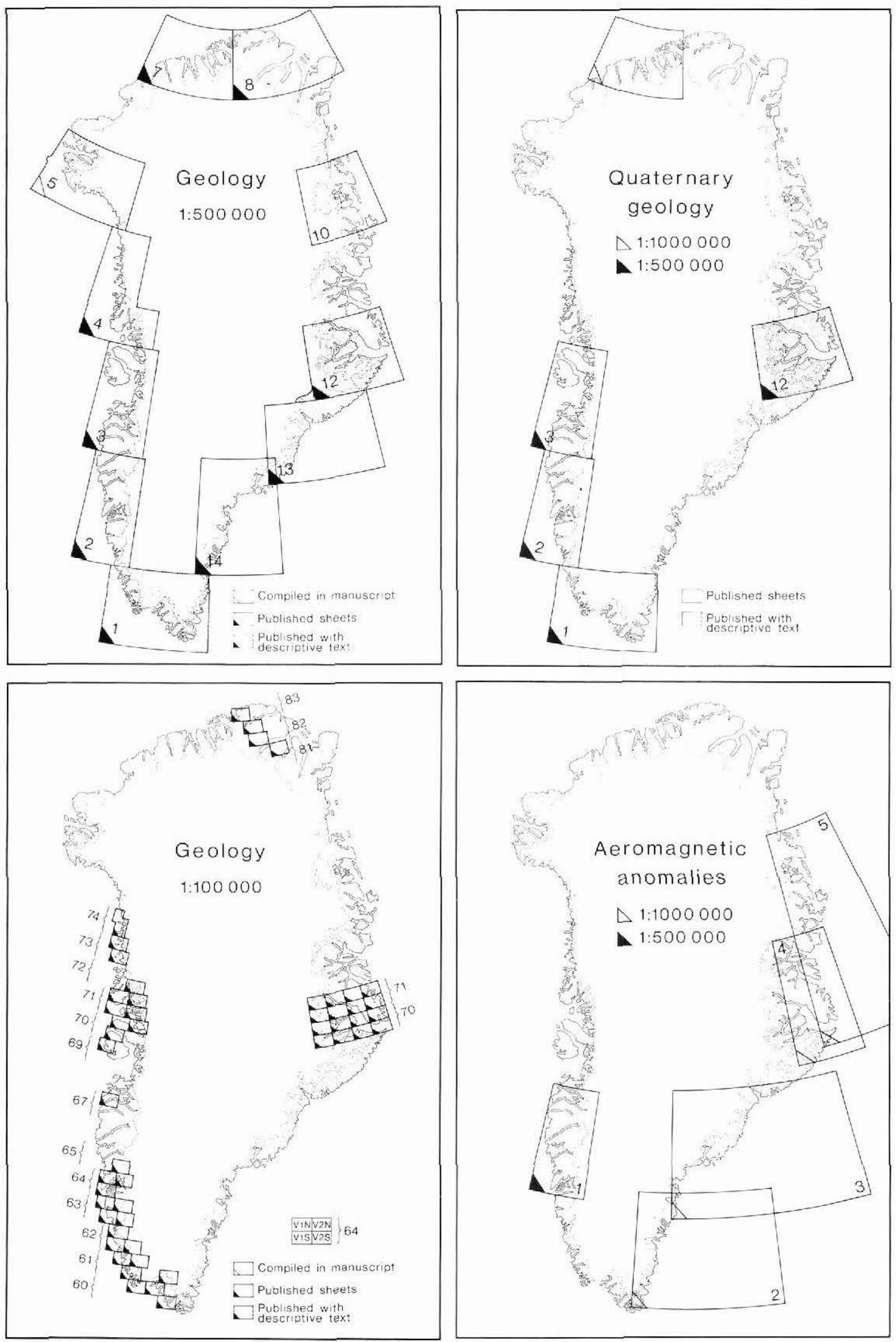

Fig. 1. Map sheets published and in preparation by the Survey. 
Braithwaite, R. J. \& Olesen, O. B. 1990: A simple energy balance model to calculate ice ablation at the margin of the Greenland ice sheet. J. Glaciol. 36, 222-228.

Braithwaite, R. J. \& Olesen, O. B. 1990: Increased ablation at the margin of the Greenland ice sheet under a greenhouseeffect climate. Ann. Glaciol. 14, 20-22.

Brooks, C. K. \& Nielsen, T. F. D. 1990: The differentiation of the Skaergaard intrusion. A discussion of Hunter and Sparks (Contrib Mineral Petrol 95: 451-461). Contr. Miner. Petrol. 104, 244-247.

Brooks, C. K., Nielsen, T. F. D. \& Rosing, M. T. [1990] [Kangerlussuaq] Et område med enestående geologiske forskningsmuligheder, 11-17. Nuna ujarassiornermi qaqutigoortunik periarfissaqarfik, 18-25. Forskning i Grønland tusaat 1-2/89, 11-25.

Bryant, I. D. \& Pickerill, R. K. 1990: Lower Cambrian trace fossils from the Buen Formation of central North Greenland: preliminary observations. Rapp. Grønlands geol. Unders. 147, 44-62.

Bryant, I. D. \& Smith, M. P. 1990: A composite tectonoeustatic origin for sandstones at the Cambrian-Ordovician boundary in North Greenland. J. geol. Soc. Lond. 147, 795-809.

Chadwick, B., Friend, C. R. L. \& Higgins, A. K. 1990: The crystalline rocks of western and southern Dove Bugt, NorthEast Greenland. Rapp. Grønlands geol. Unders. 148, 127132.

Chalmers, J. A. 1990: Seismic acquisition in sea ice - how can we start to explore offshore East Greenland? First Break 8, $51-56$.

Chalmers, J. A. 1990: Re-evaluation of the geology of the southern West Greenland shelf - Project VEST SOKKEL. Rapp. Grønlands geol. Unders. 148, 29-32.

Christiansen, F. G. 1990: A future Arctic exploration target: Lower Paleozoic in North Greenland. Oil \& Gas J. 88(7), $56-58$.

Christiansen, F. G., Olsen, H., Piasecki, S. \& Stemmerik, L. 1990: Organic geochemistry of Upper Palaeozoic lacustrine shales in the East Greenland basin. Org. Geochem. 16, 287-294.

Christiansen, F. G., Piasecki, S. \& Stemmerik, L. 1990: Thermal maturity history of the Upper Permian succession in the Wegener Halvø area, East Greenland. Rapp. Gronlands geol. Unders. 148, 109-114.

Conway Morris, S. \& Peel, J. S. 1990: Articulated halkieriids from the Lower Cambrian of north Greenland. Nature, Lond. 345, 802-805.

Dam, G. 1990: Taxonomy of trace fossils from the shallow marine Lower Jurassic Neill Klinter Formation, East Greenland. Bull. geol. Soc. Denm. 38, 119-144.

Dam, G. 1990: Palaeoenvironmental significance of trace fossils from the shallow marine Lower Jurassic Neill Klinter Formation, East Greenland. Palaeogeogr. Palaeoclimat. Palaeoecol. 79, 221-248.

Dam, G. \& Andreasen, F. 1990: High-energy ephemeral stream deltas; an example from the Upper Silurian Holmestrand Formation of the Oslo Region, Norway. Sediment. Geol. 66, 197-225.
Dam, G. \& Christiansen, F. G. 1990: Organic geochemistry and source potential of the lacustrine shales of the Late Triassic - Early Jurassic Kap Stewart Formation, East Greenland. Marine Petrol. Geol. 7, 428-443.

Dawes, P. R. 1990: Geological mapping of Greenland. Rapp. Grønlands geol. Unders. 148, 10-15.

Dawes, P. R. 1990: The North Greenland continental margin. In Grantz, A., Johnson, L. \& Sweeney, J. F. (ed.) The geology of North America L. The Arctic Ocean region, 211226. (Chapter 13). Boulder: Geological Society of America.

Dueholm, K. S. \& Pedersen, A. K. 1990: Multi-model photogrammetry applied to arctic terrains using colour slides from Greenland. Proc. 3rd int. Conf. Develop. Commerc. Util. Tech. Polar Reg., Copenhagen, 1990, 151-160.

Fortey, R. A. \& Peel, J. S. 1990: Early Ordovician trilobites and molluscs from the Poulsen Cliff Formation, Washington Land, western North Greenland. Bull. geol. Soc. Denm. 38, 11-32.

Friderichsen, J. D., Holdsworth, R. E., Jepsen, H. F. \& Strachan, R. A. 1990: Caledonian and pre-Caledonian geology of Dronning Louise Land, North-East Greenland. Rapp. Gronlands geol. Unders. 148, 133-141.

Funder, S. \& Weidick, A. 1990: Verdensrummet og muslingerne - muslinger fra Grønland fortæller om ændrede havstrømme i Nordatlanten. Varv 1990(3), 82-93.

Garde, A. A. 1990: Thermal granulite-facies metamorphism with diffuse retrogression in Archaean orthogneisses, Fiskefjord, southern West Greenland. J. metamorph. Geol. 8, 663-682.

Ghisler, M. 1990: Towards a new decade in Greenland geology. Review of the Survey's activities in 1989. Rapp. Grønlands geol. Unders. 148, 7 only.

Ghisler, M. 1990: Geographical subdivision of Greenland. Rapp. Gronlands geol. Unders. 148, 8-10.

Grocott, J. \& Pulvertaft, T. C. R. 1990: The Early Proterozoic Rinkian belt of central West Greenland. In Lewry, J. F. \& Stauffer, M. R. (ed.) The Early Proterozoic Trans-Hudson Orogen of North America. Spec. Pap. Geol Ass. Can. 37, 443-463.

Hall, R. P. \& Hughes, D. J. 1990: Precambrian mafic dykes of southern Greenland. In Parker, A. J., Rickwood, P. C. \& Tucker, D. H. (ed.) Mafic dykes and emplacement mechanisms, 497-505. Rotterdam: A. A. Balkema.

Hall, R. P., Hughes, D. J. \& Tarney, J. 1990: Early Precambrian basic rocks of Greenland and Scotland. In Hall, R. P. \& Hughes, D. J. (ed.) Early Precambrian basic magmatism, 248-272. Glasgow \& London: Blackie; New York: Chapman \& Hall.

Hansen, E. S. Dawes, P. R. 1990) Geological and sociological aspects of epilithic lichen ecology at Qaanaaq (Thule), northwestern Greenland. Arctic and Alpine Res. 22, 389400 .

Henriksen, N. 1990: Regional geology and 1:500 000 mapping in North-East Greenland. Rapp. Grønlands geol. Unders. 148, 16-20.

Henriksen, N. 1990: Geology of North and North-East Greenland. In Kotlyakov, V. N. \& Sokolov, V. E. (ed.) Arctic research. Advances and prospects. Part 1, 354-357. Moscow: Nauka. 
Higgins, A. K. 1990: Breeding of the polar wolf in Greenland Polar Rec. 26, 55-56.

Higgins, A. K. \& Weidick, A. 1990: The world's northernmost surging glacier? Z. Gletscherk. Glazialgeol. 24 [Heft 2 for 1988], 111-123.

Jakobsen, U. H. 1990: A hydrated barium silicate in unmetamorphosed sedimentary rocks of central North Greenland. Mineralog. Mag. 54, 81-89.

Kalsbeek, F. 1990: Disko Bugt Project, central West Greenland. Rapp. Grønlands geol. Unders. 148, 21-24.

Kalsbeek, F. 1990: Geochemistry in GGU. Rapp. Grønlands geol. Unders. 148, 43-45.

Larsen, H. C. 1990: The East Greenland shelf. In Grantz, A., Johnson, L. \& Sweeney, L. F. (ed.) The geology of North America L. The Arctic Ocean region, 185-210. (Chapter 12). Boulder: Geological Society of America.

Larsen, H. C. \& Pulvertaft, T. C. R. 1990: Regional marine seismic reconnaissance. Rapp. Grønlands geol. Unders. 148, 32-34.

Larsen, L. M. 1990: Basalter i Østgrønland. Varv 1990(1), 3-14.

Larsen, L. M. \& Pedersen, A. K. 1990: Volcanic marker horizons in the Maligât Formation on Disko and Nûgssuaq, and implications for the development of the southern part of the West Greenland basin in the early Tertiary. Rapp. Grønlands geol. Unders. 148, 65-73.

Larsen, P.-H., Stemmerik, L., Nielsen, T. F. D. \& Rex, D. C. 1990: Lamprophyric dykes in Revdal, Scoresby Land, East Greenland: conflicting field observations and K-Ar age determinations. Bull. geol. Soc. Denm. 38, 1-9.

Nielsen, T. F. D. 1990: Au and PGM reef in the Skaergaard intrusion, East Greenland. Newslett. int. Liaison Gp Gold Mineral. 10, 58-59.

Nielsen, T. F. D. 1990: A gold mine in East Greenland? Rapp. Grønlands geol. Unders. 148, 40-43.

Nielsen, T. F. D. \& Rosing, M. T. 1990: The Archaean Skjoldungen alkaline province, South-East Greenland. Rapp. Grønlands geol. Unders. 148, 93-100.

Nielsen, T. F. D. \& Schønwandt, H. K. 1990: Gold and platinum group metal mineralisation in the Skaergaard intrusion, southern East Greenland. Rapp. Grønlands geol. Unders. 148, 101-103.

Okulitch, A. V., Dawes, P. R., Higgins, A. K., Soper, N. J. \& Christie, R. L. 1990: Towards a Nares Strait solution: structural studies on southeastern Ellesmere Island and northwestern Greenland. Mar. Geol. 93, 369-384.

Olsen, H. 1990: Astronomical forcing of meandering river behaviour: Milankovitch cycles in Devonian of East Greenland. Palaeogeogr. Palaeoclimat. Palaeoecol. 79, 99-115.

Peel, J. S. (ed.) 1990: Lower Cambrian trace fossils from Greenland. Rapp. Grønlands geol. Unders. 147, 62 pp.

Peel, J. S. 1990: Studying the early history of life in Greenland. Rapp. Grønlands geol. Unders. 148, 54-56.

Peel, J. S. 1990: Morphology and systematic position of Tryblidium canadense Whiteaves, 1884 (Mollusca) from the Silurian of North America. Bull. geol. Soc. Denmark 38, 43-51.

Piasecki, S., Christiansen, F. G. \& Stemmerik, L. 1990: Depositional history of an Upper Carboniferous organic-rich lacustrine shale from East Greenland. Bull. Can. Petrol. Geol. 38, 273-287.
Pickerill, R. K. \& Peel, J. S. 1990: Trace fossils from the Lower Cambrian Bastion Formation of North-East Greenland. Rapp. Grønlands geol. Unders. 147, 5-43.

Pulvertaft, T. C. R. \& Chalmers, J. A. 1990: Are there Late Cretaceous unconformities in the onshore outcrops of the West Greenland basin? Rapp. Grønlands geol. Unders. 148, $75-82$.

Rasmussen, J. A., Piasecki, S., Stemmerik, L \& Stouge, S. 1990: Late Permian conodonts from central East Greenland. Neues Jb. Geol. Paläont., Abh. 178, 309-324.

Scholle, P. A., Stemmerik, L. \& Harpøth, O. 1990: Origin of a major karst-associated celestite mineralization in Karstryggen, central East Greenland. J. sedim. Petrol. 60, 397-410.

Scholle, P. A., Stemmerik, L. \& Ulmer, D. S. 1990: Historia diagenetyczna późnopermskiej facji jądra biohermy na obszarze Wegener Halvø (wschodnia Grenlandia). Przegl. geol. 1990(9), 383-387.

Schønwandt, H. K. 1990: Activities within the field of mineral resources. Rapp. Gronlands geol. Unders. 148, 37-40.

Shimizu, H., Umemoto, N., Masuda, A. \& Appel, P. W. U. 1990: Sources of iron-formation in the Archean Isua and Malene supracrustals, West Greenland: Evidence from $\mathrm{La}-\mathrm{Ce}$ and $\mathrm{Sm}-\mathrm{Nd}$ isotopic data and REE abundances. $\mathrm{Ge}$ ochim. cosmochim. Acta 54, 1147-1154.

Skjellerup, P., Smithson, S. B. \& Larsen, H. C. 1990: Deep seismic profiling in central West Greenland. Rapp. Grønlands geol. Unders. 148, 35-37.

Sønderholm, M. \& Tirsgaard, H. 1990: Sedimentological investigations of the Multicoloured 'series' (Eleonore Bay Group, Late Precambrian) in the Scoresby Land - Andrée Land region, North-East Greenland. Rapp. Grønlands geol. Unders. 148, 115-122.

Soper, N. J. \& Higgins, A. K. 1990: Models for the Ellesmerian mountain front in North Greenland: a basin margin inverted by basement uplift. J. struct. Geol. 12, 83-97.

Steenfelt, A. 1990: Geochemical patterns related to major tectono-stratigraphic units in the Precambrian of northern Scandinavia and Greenland. J. geochem. Explor. 39, 35-48.

Stemmerik, L. \& Piasecki, S. 1990: Post-Caledonian sediments in North-East Greenland between $76^{\circ}$ and $78^{\circ} 30^{\prime} \mathrm{N}$. Rapp. Grønlands geol. Unders. 148, 123-126.

Stemmerik, L., Pulvertaft, T. C. R. \& Larsen, H. C. 1990: Current activities in the field of hydrocarbon geology. Rapp. Grønlands geol. Unders. 148, 24-29.

Stemmerik, L., Scholle, P. A., Henk, F. H., Di Liegro, G., Mantovani, M. \& Ulmer, D. S. 1990: Facies mapping and reservoir evaluation of the Upper Permian Wegener Halvø Formation along the western margin of the Jameson Land basin, East Greenland. Rapp. Grønlands geol. Unders. 148, 105-108.

Surlyk, F. 1990: A Jurassic sea-level curve for East Greenland. Palaeogeogr. Palaeoclimat. Palaeoecol. 78, 71-85.

Thomassen, B. 1990: Delineation of targets for gold exploration: A case study from East Greenland. Chron. Rech. Min. 500, 51-55.

Thomsen, H. H. \& Olesen, O. B. 1990: Continued glaciological investigations with respect to hydropower and ice-climate relationships, at Pâkitsoq, Jakobshavn, West Greenland. Rapp. Grønlands geol. Unders. 148, 83-86. 
Thorning, L. \& Schønwandt, H. K. 1990: Mineral resources exploration in Greenland. Proc. 3rd int. Conf. Develop. Commerc. Util. Tech. Polar Reg., Copenhagen, 1990, 645653.

Tirsgaard, H. 1990: Den sedimentære udvikling af Mâjût Member, Eriksfjord Formationen (Prækambrium), Sydgrønland: et eksempel på tidlig riftsedimentation. Ärsskr. dansk geol. Foren. 1987-89, 11-14.

Ulff-Møller, F. 1990: Formation of native iron in sedimentcontaminated magma: I. A case study of the Hanekammen Complex on Disko Island, West Greenland. Geochim. cosmochim. Acta 54, 57-70.

Weidick, A. 1990: Investigating Greenland's glaciers. Rapp. Grønlands geol. Unders. 148, 46-51.

Weidick, A. 1990: Human activities and the ice cover of
Greenland. In Kotlyakov, V. N. \& Sokolov, V. E. (ed.) Arctic research. Advances and prospects. Part 2, 23-34. Moscow: Nauka.

Weidick, A. 1990: Possibilities of investigation of 'old ice' from other sources than deep ice cores. In Kotlyakov, V. N. \& Sokolov, V. E. (ed.) Arctic research. Advances and prospects. Part 2, 35-36. Moscow: Nauka.

Weidick, A. 1990: Glaciers and the hydropower planning for Greenland. Proc. 3rd int. Conf. Develop. Commerc. Util. Tech. Polar Reg., Copenhagen, 1990, 654-663.

Weidick, A., Oerter, H., Reeh, N., Thomsen, H. H. \& Thorning, L. 1990: The recession of the Inland Ice margin during the Holocene climatic optimum in the Jakobshavn Isfjord area of West Greenland. Palaeogeogr. Palaeoclimat. Palaeoecol. (Global planet. Change Sect.) 82, 389-399. 